\title{
INACTIVATION OF ENDOTOXIN BY A HUMORAL COMPONENT. VI. TWO SEPARATE SYSTEMS REQUIRED FOR VIABLE AND KILLED SALMONELLA TYPHOSA
}

\author{
By MAURICE LANDY, ROBERT-JOHN TRAPANI AND FRED S. ROSEN *
}

\author{
(From the Laboratory of Chemical Pharmacology, National Cancer Institute, Bethesda, Md.)
}

(Submitted for publication August 18, 1959; accepted October 2, 1959)

The blood of mammalian species contains a component which inactivates endotoxins in vitro (1). This endotoxin-detoxifying component (EDC) is identified by attributes which distinguish it from other substances in blood of known biologic activity $(2,3)$. Following appropriate interaction in vitro with this component, endotoxins from gram-negative bacteria are so altered that they no longer elicit such characteristic host reactions as the production of antibody (4), tumor damage, local skin reactivity and fatal shock. Bacterial endotoxins elicit the same host reactions which are evoked by the intact gram-negative bacilli from which they are isolated (5). It was therefore expected that the endotoxin in its native state on the bacterial surface would also be susceptible to inactivation by an agent with the distinctive properties of EDC.

This communication records the results of experiments which show that, by appropriate interaction in vitro with serum, it is possible to eliminate characteristic host-reactive properties of a typical gram-negative species. In the course of these studies with Salmonella typhosa, EDC was found to inactivate the endotoxin of bacilli which had been killed by heat or by chemical means, but not that in viable organisms; however, in the latter the endotoxin was inactivated by the serum bactericidal system consisting of antibody and complement. It is thus evident that two humoral mechanisms can function to inactivate the endotoxic properties of intact gram-negative bacilli.

\section{MATERIALS AND METHODS}

Collection of serum. Pooled serum specimens were prepared from the blood (10 or more individual donors) of mice, guinea pigs and rats. In some experiments human serum, pooled from 100 or more individuals, was employed. In other instances, animal and human serum samples were individual specimens. All serum samples

\footnotetext{
* Present address: Children's Hospital, Boston, Mass.
}

were stored at $-20^{\circ} \mathrm{C}$ in sealed glass ampoules. Plasma was obtained from blood collected in heparin, sodium citrate or ACD solution, ${ }^{1}$ and by passage of blood through a Fenwal ion exchange pack; the latter is referred to as "resin-treated" plasma.

Preparation of complement reagents. The reagents were prepared by standard methods (6) and each was checked for absence of hemolytic and/or bactericidal activity. Human serum was made deficient in the first component of complement $\left(C^{\prime} 1\right)$ by dialysis against acetate buffer ( $\mathrm{pH} 5.5, \mu=0.02$ ) for 48 hours at $4^{\circ} \mathrm{C}$. The serum was then centrifuged, and the supernatant fluid was adjusted to the desired $\mathrm{pH}$ and ionic strength with $\mathrm{NaOH}$ and $\mathrm{NaCl}$. This reagent, deficient in $\mathrm{C}^{\prime} 1$, is referred to as $\mathrm{R} 1$.

The precipitate obtained in this way (by dialysis and centrifugation) was washed twice with the dialyzing buffer and taken up in saline to original volume. This reagent is deficient in the second component of complement $\left(C^{\prime} 2\right)$ and is referred to as R2.

Human serum was made deficient in the third component of complement $\left(\mathrm{C}^{\prime} 3\right)$ by incubation for 1 hour at $37^{\circ} \mathrm{C}$ with zymosan (Fleischmann; $2 \mathrm{mg}$ per $\mathrm{ml}$ serum). This reagent is referred to as $\mathrm{R} 3$.

The fourth component of complement $\left(C^{\prime} 4\right)$ was inactivated by incubation of human serum containing 0.025 $\mathrm{M}$ hydrazine for 1 hour at $37^{\circ} \mathrm{C}$. The product, deficient in $C^{\prime} 4$, is referred to as $\mathrm{R} 4$.

Sera which had been heated for one-half hour in a water bath at $52^{\circ}$ or $56^{\circ} \mathrm{C}$ are designated $52^{\circ} \mathrm{C}$-serum and $56^{\circ} \mathrm{C}$-serum.

Human serum, deficient in properdin (RP), was prepared by incubation with zymosan (Fleischmann ; $2 \mathrm{mg}$ per $\mathrm{ml}$ ) for one hour at $17^{\circ} \mathrm{C}(7)$. This reagent retained the full hemolytic activity of the serum; its bactericidal activity against $S$. typhosa 0901 was also fully retained.

Assay of serum bactericidal activity. The bactericidal activity of serum and of the serum reagents was determined by adding the standard number of test organisms to dilutions of the material to be assayed. The mixtures were incubated for 1 hour at $37^{\circ} \mathrm{C}$, serial decimal dilutions were then made, and aliquots of each were plated in duplicate on meat extract agar, to ascertain the number of viable organisms remaining in the reaction mixture.

Preparation of bacterial suspensions. Meat extract

\footnotetext{
1 Twenty-two $\mathrm{g}$ trisodium citrate, $8 \mathrm{~g}$ citric acid, and $25 \mathrm{~g}$ dextrose per $\mathrm{L}$ of water; $15 \mathrm{ml}$ of this solution was added to each $100 \mathrm{ml}$ of whole blood.
} 
agar plates were inoculated with $S$. typhosa 0901 and incubated at $37^{\circ} \mathrm{C}$ for 18 hours. The growth was harvested in saline and seeded heavily on the surface of veal-infusion agar plates. Following incubation for 5 hours at $37^{\circ} \mathrm{C}$ the bacteria, in the log phase of growth, were again harvested in saline. The optical density of appropriate dilutions of this harvest was read in a KlettSummerson photometer and an estimate of the concentrations of viable organisms was made by plotting photometric readings on a standard curve of optical density vs. viable count. Serial dilutions of the suspension were plated out on meat extract agar to verify, by viable count, the bacterial concentration estimated by photometry.

Suspensions of killed organisms were prepared by heating aliquots of the $S$. typhosa suspension in a water bath at $56^{\circ} \mathrm{C}$ for 1 hour in stoppered tubes or by incubating the suspension at $37^{\circ} \mathrm{C}$ for 2 hours with merthiolate in a final concentration of 0.1 per cent.

Interaction of serum and S. typhosa. For determination of capacity of serum to inactivate the endotoxin of $S$. typhosa, various dilutions of serum were incubated for 1 hour at $37^{\circ} \mathrm{C}$ with a standard number of organisms. Quantities of reactants employed were such as would provide sufficient material for subsequent test in animals; in these tests each mouse routinely received $6 \times 10^{7}$ organisms. One $\mathrm{ml}$ of a suspension containing $6 \times 10^{8}$ organisms per $\mathrm{ml}$, enough for test in 10 mice, was incubated with $2 \mathrm{ml}$ of the desired dilution of serum. After incubation the volume was made up to $5 \mathrm{ml}$ with sterile saline; each mouse received $0.5 \mathrm{ml}$ of the reaction mixture, i.e., $6 \times 10^{7}$ organisms.

The variable in these tests was the dilution of serum (or serum reagent) incubated with a constant number of bacilli. Although the procedure outlined above is given in terms of the quantity required for a group of 10 mice, the data presented in this report are presented in terms of the quantity administered per mouse.

Assay of endotoxic potency of typhoid bacilli and its inactivation by serum. Sarcoma 37 was implanted into the thigh muscle of young $\mathrm{CAF}_{1}$ mice (2 to 3 months old); $0.05 \mathrm{ml}$ of a tumor mash was the amount injected. Six days later, 200 mice bearing such implants were randomly distributed into groups of 10 each. Each set of bioassays included two control groups : the first consisted of 10 untreated mice, to disclose the extent of spontaneous hemorrhage or necrosis in the tumors of the set; the second one consisted of 10 mice which had been given the standard dose of $6 \times 10^{7}$ typhoid bacilli for estimation of the level of responsiveness of the set of tumors to endotoxin (8). This number of organisms $\left(6 \times 10^{7}\right)$ was sufficient to induce marked hemorrhage and necrosis in the tumors within 24 hours, but it was small enough to permit the diminution or elimination of this endotoxic activity to be readily detected. The mice were injected intraperitoneally with $0.5 \mathrm{ml}$ aliquots of the test mixtures described above. On the following day the animals were sacrificed and the tumors bisected and examined for induced tumor damage. The experimental groups were scored on the basis of comparison with the two control groups. When no tumor damage was evident it was obvious that the bacterial endotoxin had been inactivated. Intermediate degrees of tumor damage showed that partial inactivation had occurred. When tumor damage was equal in severity to that in the control group given untreated bacteria, no significant inactivation of the bacterial endotoxin had occurred.

Assay of antigenicity in rabbits. The effect of serum reagents on the antigenicity of $S$. typhosa 0901 was determined by incubation of the reagents with the standard dose $\left(10 \times 10^{\circ}\right.$ organisms $)$ for 1 hour at $37^{\circ} \mathrm{C}$. The number of bacilli and the test conditions were the same for experiments with either killed or viable organisms. Amounts of reactants were chosen to be sufficient for test in groups of rabbits ( 5 animals per group). After incubation, each mixture was diluted with an appropriate amount of saline so that each animal received intravenously $10 \times 10^{\circ}$ serum-reacted bacilli in a volume of $2.0 \mathrm{ml}$. Each experiment included a control group of rabbits given the same dose of bacilli incubated in saline. Rabbits of a single breed (New Zealand albino females, weighing 2 to $2.5 \mathrm{~kg}$ ) from a single source (National Institutes of Health animal unit) were employed throughout. Six days after the single intravenous immunizing injection the animals were bled and the typhoid $\mathrm{O}$ agglutinin titers of the sera were determined. For the agglutination tests, equal volumes of serial twofold dilutions of rabbit serum and a suspension of heat-killed $S$. typhosa $0901\left(1 \times 10^{9}\right.$ organisms per $\left.\mathrm{ml}\right)$ were incubated for 18 hours at $52^{\circ} \mathrm{C}$. Agglutination was read macroscopically, and the highest serum dilution in which agglutination was clearly visible was recorded as the titer.

\section{RESULTS}

The choice of a host indicator reaction for the assay of endotoxic potency is of prime importance in determining whether the endotoxin of intact bacilli is altered by agents in normal blood. Our previous work on the inactivation of purified endotoxin by EDC indicated that the most sensitive and consistent evidence of alterations in endotoxin was provided by indicator systems such as the induction of hemorrhagic necrosis in sarcoma implants of mice and the production of antibody in rabbits. Accordingly, these were the methods of choice for the present work. The basic observations on the detoxification of intact bacilli, which constitute the first part of this experimental section, were made with the use of the tumor damage assay. Then the requirements for such a detoxifying effect were further substantiated by determining changes in the antigenic properties of these bacilli.

Induction of tumor damage by heat-killed bacilli. Typhoid bacilli, killed by exposure to $56^{\circ} \mathrm{C}$ for 60 
TABLE I

Inactivation of purified endotoxin and killed bacilli by human plasma: Suppression of the effect by calcium ion

\begin{tabular}{|c|c|c|c|c|}
\hline Human plasma & & Endotoxin & $\begin{array}{l}\text { Induced } \\
\text { tumor } \\
\text { damage* }\end{array}$ & $\begin{array}{l}\text { Inactiva- } \\
\text { tion of } \\
\text { endotoxin }\end{array}$ \\
\hline & $m l$ & & & \\
\hline $\begin{array}{c}\text { ACD pooled } \\
\text { ACD pooled recalcified } \dagger\end{array}$ & $\begin{array}{l}\left\{\begin{array}{l}0.1 \\
0.05 \\
0.025 \\
0.1\end{array}\right. \\
\text { none }\end{array}$ & $\begin{array}{c}5 \mu \mathrm{g} \\
\text { S. typhosa } \\
\text { lipopolysaccharide }\end{array}$ & $\begin{array}{r}0 / 10 \\
0 / 10 \\
2 / 10 \\
9 / 10 \\
10 / 10\end{array}$ & $\begin{array}{l}\text { complete } \\
\text { complete } \\
\text { complete } \\
\text { none } \\
\text { none }\end{array}$ \\
\hline $\begin{array}{c}\text { ACD pooled } \\
\text { ACD pooled recalcified } \dagger\end{array}$ & $\begin{array}{l}\left\{\begin{array}{l}0.1 \\
0.05 \\
0.025\end{array}\right. \\
0.1 \\
\text { none }\end{array}$ & $\begin{array}{c}1 \times 10^{8} \\
\text { heat-killed } \\
\text { S.typhosa }\end{array}$ & $\begin{array}{c}0 / 10 \\
2 / 10 \\
5 / 9 \\
10 / 10 \\
10 / 10\end{array}$ & $\begin{array}{l}\text { complete } \\
\text { complete } \\
\text { partial } \\
\text { none } \\
\text { none }\end{array}$ \\
\hline
\end{tabular}

* Number of mice with damaged tumors/total number of mice tested.

$+\mathrm{Ca}^{++} 2.5 \times 10^{-2} \mathrm{M}$.

minutes, were found to induce tumor damage in a manner qualitatively indistinguishable from that of the endotoxin isolated from the same organisms. The minimal number of bacilli which induced significant hemorrhagic necrosis in the sarcoma implants was in the order of 30 million organisms, but 60 or 100 million organisms were routinely employed to assure the consistent and uniform induction of tumor damage of appropriate severity.

Inactivation of heat-killed bacilli. Incubation of heat-killed bacilli with citrated human plasma rendered these organisms inactive as tumor-damaging agents. Matched specimens of serum and plasma from a single donor were titrated for their inactivating potency. It was found that serum and heparinized plasma had little effect on the tumordamaging activity of the killed bacilli, whereas citrated and resin-treated plasma were highly potent. These experiments indicated that divalent cation suppressed the effect of this agent in the blood. Evidence that isolated endotoxin and heatkilled bacilli are inactivated by the same agent is presented in Table I. The conditions of time and temperature required to inactivate the bacilli were similar to those previously established for the alteration of isolated endotoxin by EDC. Furthermore, in both instances, inactivation failed to take place when the reactants were administered separately or were merely admixed and injected without any incubation. Experiments with typhoid bacilli, which had been killed with merthiolate, gave identical results. These data show that the endotoxin of killed typhoid bacilli is inactivated by an agent in blood which, like EDC, can be suppressed by divalent cation.

Induction of tumor damage by viable bacilli. The tumor-damaging potency of aliquots of a harvest of $S$. typhosa were titrated; it was found that 15 million viable organisms produced significant tumor damage, whereas 30 million of the heat-killed bacilli were required for the same effect. To assure a uniformly high degree of hemorrhagic necrosis the quantity of viable organisms routinely employed for induction of tumor damage was increased to 60 million. As will be brought out later in this report, no significant multiplication of these organisms occurs in the peritoneal cavity during a period of at least four hours after injection. Moreover, pretreatment of the mice with chloramphenicol did not affect the induction of tumor damage by 60 million organisms. These findings indicate that the observed tumor damage was evoked primarily by the number of bacteria which were injected and was not the result of further bacterial growth in the mouse peritoneal cavity.

Inactivation of viable bacilli. Pilot experiments in which viable bacilli were incubated with human serum or plasma showed that the tumor-damaging effect of these bacilli could be eliminated by serum. However, it soon became evident that this effect was not correlated with EDC activity. For example, human serum, to which calcium was added to suppress EDC activity, was still effective in eliminating the tumor-damaging activity of the organisms. Guinea pig serum, which likewise man- 
ifested no EDC activity, was equally potent. On the other hand mouse citrated plasma with good EDC activity was without effect on the endotoxin of viable bacilli. The findings presented in Table II emphasize that the requirements for the inactivation of viable bacilli are quite different from those for the inactivation of bacilli killed by heat.

Serum bactericidal activity and inactivation of viable bacilli. Specimens of fresh serum from eight animal species were interacted with viable $S$. typhosa to determine whether they were capable of abolishing tumor-damaging activity. With the exception of mouse serum, sera of all species were effective. This conspicuous lack of effect of mouse serum (9) on the tumor-damaging potency of viable organisms provided the first indication that only serum with bactericidal activity was capable of bringing about this change. Rabbit serum was the least potent, followed by horse, rat, sheep, dog, guinea pig and human sera, in increasing order of potency. Guinea pig and human sera consistently exhibited the most pronounced effect. The fact that many of these sera had previously been shown to lack EDC activity was further evidence that another agent was involved in the inactivation of viable bacilli.

These sera were examined for their in vitro bactericidal activity against the test organism. Although a precise correlation was not established, the in vitro bactericidal potency and the capability of these sera to inactivate the endotoxic effects of viable typhoid bacilli were comparable. Human and guinea pig sera were the most potent in both situations whereas rabbit serum was the least effective.

\section{TABLE II}

Evidence for the involvement of different systems in the inactivation of viable and killed typhoid bacilli

\begin{tabular}{lcc}
\hline \hline & $\begin{array}{c}\text { Effect on tumor-damaging } \\
\text { capacity of } S \text {. typhosa } \\
\text { suspensions* }\end{array}$ \\
\cline { 2 - 3 } $\begin{array}{c}\text { Products interacted with } \\
\text { typhoid bacilli }\end{array}$ & $\begin{array}{c}6 \times 10^{7} \text { heat- } \\
\text { killed cells }\end{array}$ & $\begin{array}{c}6 \times 10^{7} \text { viable } \\
\text { cells }\end{array}$ \\
\hline $\begin{array}{l}\text { Guinea pig serum } \\
\text { Mouse citrated plasma } \\
\left.\text { (sodium citrate } 2 \times 10^{-2} \mathrm{M}\right)\end{array}$ & none & inactivated \\
$\begin{array}{c}\text { Human serum with added } \\
\text { Cat+ }\left(2.7 \times 10^{-2} \mathrm{M}\right)\end{array}$ & none & none \\
$\begin{array}{c}\text { Human resin-treated plasma } \\
\text { inactivated }\end{array}$ & inactivated & inactivated
\end{tabular}

* Prepared from a common harvest; 1 aliquot was heated at $56^{\circ} \mathrm{C}$ for 1 hour.
TABLE III

Bactericidal action of normal human serum on S. typhosa 0901: Requirements for the effect

\begin{tabular}{|c|c|c|}
\hline \multicolumn{2}{|c|}{ Serum reagent tested* } & $\begin{array}{l}\text { Viable } \\
\text { count } \\
\times 10^{6}\end{array}$ \\
\hline $\begin{array}{c}\text { Fresh human serum } \\
\text { Fresh human serum } \\
\text { Fresh human serum } \\
\text { Fresh human serum } \\
\\
\text { Fresh human serum } \\
\text { Fresh human serum } \\
\text { R1 } \\
\text { R2 } 8 \\
\text { R3 } \\
\text { R4 } \\
\text { RP } \\
\text { Control }\end{array}$ & $\begin{array}{l}\text { untreated } \\
\text { absorbed with } S . t y p h i \dagger \\
\text { absorbed with } S . t y p h i, \dagger \\
\text { antibody } \ddagger \text { added } \\
\text { absorbed with Serr. } \\
\text { marcescenst } \\
\text { chelated (EDTA) } \\
\Delta 56^{\circ} \mathrm{C}, \frac{1}{2} \mathrm{hr} \\
\text { (dialysis) } \\
\left(\Delta 52^{\circ} \mathrm{C}, \frac{1}{2} \mathrm{hr} \text { ) }\right. \\
\left.\text { (zymosan, } 37^{\circ} \mathrm{C}\right) \\
\text { (hydrazine) } \\
\text { (zymosan, } 17^{\circ} \mathrm{C} \text { ) } \\
\text { (saline) }\end{array}$ & $\begin{array}{l}0.0038 \\
7.7 \\
8.9 \\
5.0 \\
11.6 \\
8.0 \\
8.2 \\
0.0023 \\
9.1\end{array}$ \\
\hline
\end{tabular}

* Two-tenths $\mathrm{ml}$ of each of these reagents was incubated for 1 hour at $37^{\circ} \mathrm{C}$, with $10 \times 10^{6} \mathrm{~S}$. typhosa.

$\dagger$ One $\mathrm{ml}$ of human serum was absorbed with $0.1 \mathrm{ml}$ of packed, washed, heat-killed organisms for 3 hours at $4^{\circ} \mathrm{C}$.

$\ddagger$ One-tenth $\mathrm{ml}$ of a $1: 10,000$ dilution of rabbit antiserum to typhoid endotoxin (220 $\mu \mathrm{g}$ antibody nitrogen per $\mathrm{ml}$ ) added to the absorbed serum.

\& 2 prepared by dialysis yielded similar results.

Requirements for bactericidal action of human serum on S. typhosa 0901. Experiments were conducted to determine the components in normal human serum required for bactericidal action against $S$. typhosa 0901. As is seen in Table III, all of the four recognized components of complement, plus divalent cation and specific antibody are needed, but properdin is not required. The inactivation or removal of any one of these six components of the system resulted in loss of bactericidal activity. It is noteworthy that normal human serum without typhoid antibody, demonstrable by either bacterial or hemagglutination procedures, was nonetheless highly active in the killing of bacteria. However, absorption of such sera with the test organism resulted in complete loss of bactericidal activity. This activity was fully restored upon the addition of an impressively small amount of rabbit antityphoid serum (0.002 $\mu \mathrm{g}$ antibody nitrogen). This observation was not limited to human serum but was also true of guinea pig and sheep sera which were tested in this regard. Therefore, the amount of antibody present in normal serum could be exceedingly small, indeed undetectable by available methods, and yet suffice for this reaction.

Effect of complement-deficient serum reagents 
TABLE IV

Capacity of various complement reagents to eliminate the induction of tumor damage by viable bacilli

\begin{tabular}{lclcl}
\hline Serum reagents* & $\begin{array}{c}\text { Dilution } \\
\text { employed } \\
(\mathbf{0 . 2} \mathrm{ml})\end{array}$ & Endotoxin & $\begin{array}{c}\text { Induced } \\
\text { tumor } \\
\text { damaget }\end{array}$ & $\begin{array}{c}\text { Inactiva- } \\
\text { tion of } \\
\text { endo- } \\
\text { toxin }\end{array}$ \\
\hline Normal human & & & & \\
$\quad$ serum & $1: 16$ & & $2 / 10$ & complete \\
R1 & $1: 16$ & $6 \times 10^{7}$ & $1 / 10$ & complete \\
R2 $\ddagger$ & $1: 2$ & viable & $9 / 9$ & none \\
R3 & $1: 2$ & S.typhosa & $8 / 8$ & none \\
R4 & $1: 16$ & & $1 / 10$ & complete \\
RP & $1: 16$ & & $2 / 10$ & complete \\
Controls (saline) & & & $10 / 10$ & none \\
& & & &
\end{tabular}

* These reagents were incubated with the test organisms for 1 hour at $37^{\circ} \mathrm{C}$ prior to injection.

+ Number of mice with damaged tumors/total number of mice tested.

$\ddagger$ Prepared by dialysis.

in vivo. It was found that serum rendered deficient in one or another of the components of complement, and thus no longer bactericidal, was still capable of inactivating the tumor-damaging capacity of the organisms following intraperitoneal injection into mice (Table IV). R1 and R4 were as effective as whole serum in their ability to inactivate the tumor-damaging potency of the viable bacilli. On the other hand, R2 and R3 no longer exhibited any activity in this regard, and serum exposed to $56^{\circ} \mathrm{C}$ for 30 minutes was likewise ineffective. However, an R2 prepared by heating serum at $52^{\circ} \mathrm{C}$ for an equal length of time still was capable of eliminating tumor-damaging activity of viable organisms. Heating of serum at

\section{TABLE $V$}

Ineffectiveness in vitro of heated serum on the toxicity of viable bacilli

\begin{tabular}{|c|c|c|c|}
\hline \multirow[b]{2}{*}{$\begin{array}{l}\text { Serum reagents interacted } \\
\text { with bacteria* }\end{array}$} & \multicolumn{2}{|c|}{$\begin{array}{l}\text { Tumor damage induced } \dagger \\
\text { in mice by inter- } \\
\text { action products }\end{array}$} & \multirow[b]{2}{*}{$\begin{array}{l}\text { Inacti- } \\
\text { vation } \\
\text { of } \\
\text { endo- } \\
\text { toxin }\end{array}$} \\
\hline & $\begin{array}{l}\text { Entire } \\
\text { inter- } \\
\text { action } \\
\text { mixture }\end{array}$ & $\begin{array}{l}\text { Centri- } \\
\text { fuged } \\
\text { bacteria }\end{array}$ & \\
\hline $\begin{array}{l}\text { Human serum } \\
\text { Human serum } \Delta 52^{\circ} \mathrm{C}, \frac{1}{2} \mathrm{hr} \\
\text { Human serum } \Delta 56^{\circ} \mathrm{C}, \frac{1}{2} \mathrm{hr} \\
\text { Controls (saline) }\end{array}$ & $\begin{array}{r}0 / 10 \\
0 / 10 \\
8 / 10 \\
10 / 10\end{array}$ & $\begin{array}{l}0 / 10 \\
8 / 10 \\
7 / 10 \\
8 / 10\end{array}$ & $\begin{array}{l}\text { in vitro } \\
\text { in vivo } \\
\text { nolie }\end{array}$ \\
\hline
\end{tabular}

* S. typhosa $\left(6 \times 10^{7}\right)$ incubated with $0.1 \mathrm{ml}$ of serum for 1 hour at $37^{\circ} \mathrm{C}$.

$\dagger$ Number of mice with damaged tumors/total number of mice tested.

\pm Reaction mixtures centrifuged at $30,000 \mathrm{G}$ for 1 hour at $4^{\circ} \mathrm{C}$. For injection, sedimented bacteria were made up to initial reaction volume with saline. $56^{\circ} \mathrm{C}$ is known to render it completely deficient in $\mathrm{C}^{\prime} 1$ and $\mathrm{C}^{\prime} 2$, whereas heating at $52^{\circ} \mathrm{C}$ results in complete loss of only $\mathrm{C}^{\prime 2}(6)$. Evidence that these complement reagents were producing their effect in vivo was obtained in the experiment summarized in Table V. When the reaction of serum and viable organisms was carried out in an in vitro environment, neither the reaction mixture nor the bacteria removed by centrifugation produced tumor damage. On the other hand, incubation of organisms in serum rendered nonbactericidal by heating at $52^{\circ} \mathrm{C}$ yielded cells with essentially undiminished endotoxic potency. It is seen from this experiment that no loss of capacity to elicit tumor damage occurs after incubation of viable bacilli in nonbactericidal serum reagents. Thus the effectiveness of such reagents as $\mathrm{R} 1, \mathrm{R} 4$ and $52^{\circ} \mathrm{C}$ heated serum was due to events which occurred after injection into the mouse peritoneal cavity.

Limiting interval for inactivation in vivo of viable bacilli by serum. It was presumed that the effective complement reagents supplemented, and thus accelerated, the mouse's own mechanisms for coping with the injected bacteria. It was further reasoned that the tumor-damage reaction was fixed within a certain time limit. Thus, the presence or absence of effect by these various complement reagents would depend upon their ability to produce accelerated killing of these organisms in the peritoneal cavity of the mouse. To ascertain the validity of this assumption, the following experiment was performed. The standard dose of viable typhoid bacilli was injected intraperitoneally into groups of mice which were then given whole human serum intraperitoneally at different intervals, ranging from 15 to 120 minutes. These results are summarized in Table VI and show that the administration of serum, at any time up to 60 minutes after the bacterial injection, completely prevented the occurrence of tumor damage, whereas serum injected at 90 to 120 minutes did not. Serum administered 30 minutes prior to or at the same time as the bacteria was effective. On the other hand, serum administered by the intravenous route did not prevent the induction of tumor damage by the microorganisms. These data show that the viable bacteria would elicit the characteristic endotoxic reaction in the host, leading to hemorrhagic necrosis in the tumor implants, unless these or- 
ganisms were acted upon and killed within a well defined time limit.

Effect of serum concentration on inactivation of viable bacilli in viv'o. To determine the minimal amount of human serum which was effective in eliminating tumor damage, decreasing amounts of serum were administered intraperitoneally $15 \mathrm{~min}$ utes after mice had been given the standard dose of $6 \times 10^{7}$ viable bacilli. The results of this test are given in Table VII, in which the effectiveness of different dilutions of fresh human serum was compared with various dilutions of heated serum.

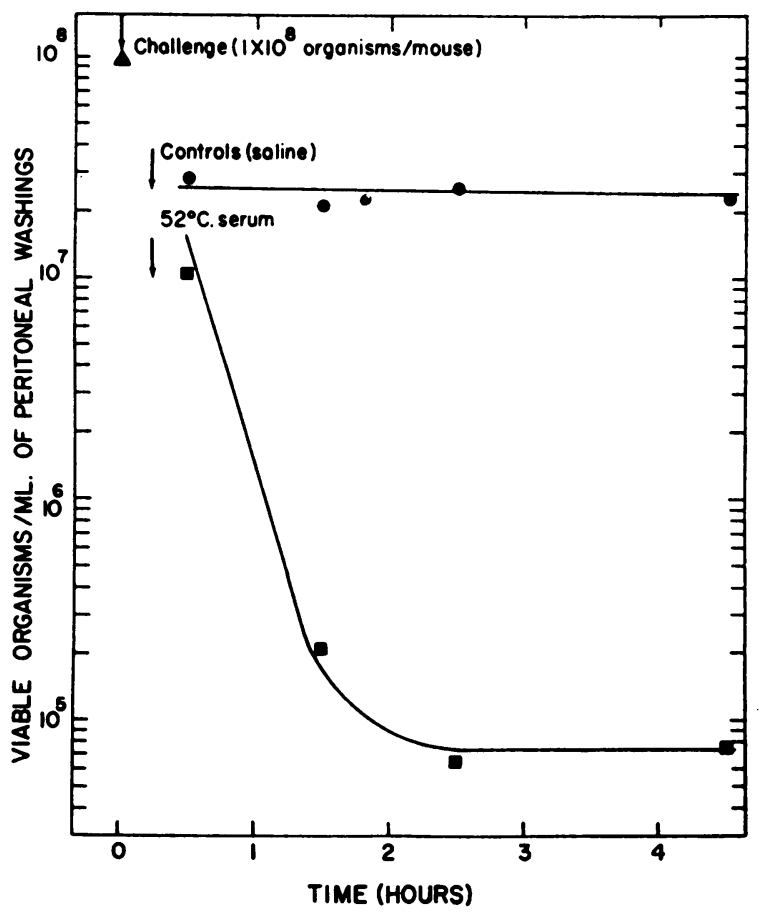

Fig. 1. BACTERICIDAL EFFECT OF $52^{\circ} \mathrm{C}$ - HUMAN SERUM ON $S$. TYPHOSA IN THE MOUSE PERITONEAL CAVITY.

It is seen that $52^{\circ} \mathrm{C}$-heated serum was capable of eliminating the reactivity of viable organisms, but its potency in this regard was considerably less than that of untreated serum.

Reduction of bacterial populations by serum in vivo. Experiments were performed in which the bacterial populations in the mouse peritoneal cavity were determined at varying intervals after the separate administration of serum heated at $52^{\circ} \mathrm{C}$. Two groups of mice received $6 \times 10^{7} S$. typhosa intraperitoneally; 15 minutes thereafter the mice of one group were given $0.1 \mathrm{ml}$ of serum heated
TABLE VI

Timing of serum administration as a prerequisite for in vivo inactivation of viable bacilli

\begin{tabular}{cccl}
\hline Endotoxin & $\begin{array}{c}\text { Interval } \\
\text { between ip } \\
\text { injection } \\
\text { of bacilli } \\
\text { and serum* }\end{array}$ & $\begin{array}{c}\text { Induced } \\
\text { tumor } \\
\text { damaget }\end{array}$ & $\begin{array}{c}\text { Inactiva- } \\
\text { tion of } \\
\text { endotoxin }\end{array}$ \\
\hline & min & & \\
$6 \times 10^{7}$ & 15 & $0 / 10$ & complete \\
viable & 30 & $2 / 9$ & complete \\
S.typhosa & 45 & $0 / 10$ & complete \\
& 60 & $4 / 10$ & partial \\
& 75 & $8 / 10$ & none \\
& 90 & $9 / 10$ & none \\
& 120 & $8 / 9$ & none \\
& & $8 / 9$ & \\
\hline
\end{tabular}

* Two-tenths $\mathrm{ml}$ of a 1:2 dilution of normal human serum. $\uparrow$ Number of mice with damaged tumors/total number of mice tested.

at $52^{\circ} \mathrm{C}$, while each mouse of the other group received an equal volume of saline. Ten mice from the experimental or control groups were sacrificed at $15,60,120$ and 240 minutes following this administration of the serum or saline. The peritoneal contents of each of the ten mice were taken up in saline and pooled; serial dilutions were plated for the determination of the viable bacterial count. The results of one such experiment. typical of three performed, are shown in Figure 1. It was observed consistently that the number of bacteria in the peritoneal cavity of the control animals remained relatively unchanged during the four hour test period. In contrast, the animals receiving serum showed a rapid and marked re-

TABLE VII

Quantity of serum required for in vivo inactivation of viable bacilli

\begin{tabular}{|c|c|c|c|c|}
\hline \multirow[b]{2}{*}{ Endotoxin } & \multicolumn{2}{|c|}{ Human serum* } & \multirow{2}{*}{$\begin{array}{l}\text { Induced } \\
\text { tumor } \\
\text { damaget }\end{array}$} & \multirow{2}{*}{$\begin{array}{l}\text { Inactiva- } \\
\text { tion of } \\
\text { endo- } \\
\text { toxin }\end{array}$} \\
\hline & $\begin{array}{l}\text { Exposure } \\
\text { to heat }\end{array}$ & $\begin{array}{c}\text { Dose } \\
(0.2 \mathrm{ml})\end{array}$ & & \\
\hline \multirow{4}{*}{$\begin{array}{c}6.10^{7} \\
\text { viable } \\
S . \text { typhosa }\end{array}$} & none & $\begin{array}{l}1: 8 \\
1: 16 \\
1: 24\end{array}$ & $\begin{array}{l}1 / 9 \\
0 / 7 \\
9 / 10\end{array}$ & $\begin{array}{l}\text { complete } \\
\text { complete } \\
\text { none }\end{array}$ \\
\hline & $52^{\circ} \mathrm{C}, \frac{1}{2} \mathrm{hr}$ & $\begin{array}{l}1: 2 \\
1: 4 \\
1: 8\end{array}$ & $\begin{array}{l}1 / 10 \\
3 / 10 \\
7 / 10\end{array}$ & $\begin{array}{l}\text { complete } \\
\text { partial } \\
\text { none }\end{array}$ \\
\hline & $56^{\circ} \mathrm{C}, \frac{1}{2} \mathrm{hr}$ & $1: 2$ & $9 / 10$ & none \\
\hline & & & $9 / 10$ & \\
\hline
\end{tabular}

* Administered ip 15 min following injection of bacteria. $\dagger$ Number of mice with damaged tumors/total number of mice tested. 
TABLE VIII

Bactericidal action of normal mouse serum when supplemented by human serum reagents

\begin{tabular}{lc}
\hline \multicolumn{1}{c}{ Serum reagents tested* } & $\begin{array}{c}\text { Viable } \\
\text { count } \\
\times 10^{\circ}\end{array}$ \\
\hline $\begin{array}{l}0.2 \mathrm{ml} \text { normal mouse serum } \\
0.2 \mathrm{ml} \text { normal mouse serum }+0.2 \mathrm{ml} \text { human } \\
\text { serum } \Delta 52^{\circ} \mathrm{C}, \frac{1}{2} \mathrm{hr}\end{array}$ & 10.0 \\
$\begin{array}{l}0.2 \mathrm{ml} \text { normal mouse serum }+0.1 \mathrm{ml} \text { human } \\
\text { serum } \Delta 52^{\circ} \mathrm{C}, \frac{1}{2} \mathrm{hr}\end{array}$ & 0.023 \\
$\begin{array}{l}0.2 \mathrm{ml} \text { normal mouse serum }+0.05 \mathrm{ml} \text { human } \\
\text { serum } \Delta 52^{\circ} \mathrm{C}, \frac{1}{2} \mathrm{hr}\end{array}$ & 0.46 \\
$\begin{array}{l}0.2 \mathrm{ml} \text { normal mouse serum }+0.025 \mathrm{ml} \text { human } \\
\text { serum } \Delta 52^{\circ} \mathrm{C}, \frac{1}{2} \mathrm{hr}\end{array}$ & 1.78 \\
$\begin{array}{l}0.2 \mathrm{ml} \text { normal mouse serum }+0.2 \mathrm{ml} \text { human } \\
\text { serum } \Delta 56^{\circ} \mathrm{C}, \frac{1}{2} \mathrm{hr}\end{array}$ & 7.9 \\
$\begin{array}{l}0.2 \mathrm{ml} \text { normal mouse serum }+0.2 \mathrm{ml} \text { human } \\
\text { serum } \mathrm{R3}\end{array}$ & 8.9 \\
$\begin{array}{l}0.2 \mathrm{ml} \text { mouse serum } \Delta 52^{\circ} \mathrm{C}, \frac{1}{2} \mathrm{hr}+0.2 \mathrm{ml} \\
\text { human serum } \Delta 52^{\circ} \mathrm{C}, \frac{1}{2} \mathrm{hr}\end{array}$ & 8.1 \\
\begin{tabular}{l} 
Controls (saline) \\
\hline
\end{tabular} & 8.6 \\
\hline
\end{tabular}

* These products were incubated at $37^{\circ} \mathrm{C}$ for 1 hour with $10 \times 10^{6} S$. typhosa after which serial dilutions of the reaction mixtures were plated for viable count.

duction in bacterial numbers which occurred within one hour. This is the time interval in which $52^{\circ}$ $\mathrm{C}$-heated serum, or any other effective complement reagent, must be given to eliminate the tumor-damaging activity of the bacteria.

Bactericidal activity of mouse serum combined with human complement reagents. Normal mouse serum was combined with one or another of the complement-deficient reagents, and these combinations were examined for their bactericidal activity in order to determine whether these in vivo bactericidal effects could be duplicated in vitro. The results of such an experiment, given in Table VIII, show that nonbactericidal mouse serum, combined with inactivated $\left(56^{\circ} \mathrm{C}\right)$ human serum or R3 was not bactericidal. However, when mouse serum was added to human serum which had been heated at $52^{\circ} \mathrm{C}$, pronounced bactericidal activity was obtained; as little as $0.05 \mathrm{ml}$ of the $52^{\circ} \mathrm{C}$ serum with $0.2 \mathrm{ml}$ of mouse serum sufficed to elicit significant bactericidal activity. On the other hand, such heated human serum, combined with mouse serum which had been similarly heated at $52^{\circ} \mathrm{C}$, did not provide a bactericidal combination.

From these data, and those obtained in the preceding experiments, it became clear that those complement-deficient reagents which were effective in vivo were equally effective as bactericidal agents when combined in vitro with mouse serum.

Ineffectiveness of complement reagents in the levan-treated mouse. It has been reported (10) that the intravenous injection of levan inhibits the transcapillary transfer of humoral factors of the mouse and thereby permits the unhindered growth of intraperitoneally-injected gram-negative bacteria. This experimental model was utilized to show that human complement reagents were effective in vivo only by virtue of supplementation with humoral factors present in the mouse. $\mathrm{Tu}$ mor-bearing mice were given $3 \mathrm{mg}$ of levan ${ }^{2}$ intravenously, followed by the intraperitoneal injection of $2 \times 10^{6} S$. typhosa. Mice so treated exhibited marked tumor damage, whereas nonlevanized, tumor-bearing mice did not react to this small dose of bacilli. Reagents such as $52^{\circ} \mathrm{C}$-serum and $\mathrm{R} 4$ prevented tumor damage induced by as many as $6 \times 10^{7}$ bacilli in nonlevanized mice. However, these reagents were ineffective in mice which had been prepared with levan, whereas whole human serum was effective. These data offer further support for the view that the efficacy of certain complement-deficient reagents is dependent upon the transfer of humoral factors from the mouse circulation to the peritoneal cavity. Antigenicity for rabbits of viable and killed $S$. typhosa. The production of antibody by rabbits in response to $S$. typhosa was employed as an indicator of host reactivity to endotoxin in order to extend the previous observations on the changes produced in the endotoxin of intact bacilli by humoral agents. Groups of rabbits were given single intravenous injections of viable or of heat-killed bacilli prepared from a common harvest. As little as $0.1 \times 10^{6}$ organisms sufficed to evoke measurable levels of antibody. As the immunizing dose was increased by tenfold increments the agglutinin titers rose sharply. Mean titers for rabbits receiving $1 \times 10^{6}$ killed organisms was $1: 280$ and that for viable bacilli was $1: 720 ; 10 \times 10^{\circ}$ gave mean titers of $1: 1,350$ for killed bacilli and

2 We are indebted to Dr. M. Shilo for providing us with a supply of purified Aerobacter levan and his unpublished manuscript on the mechanism of the infectionpromoting activity of levan. 
TABLE IX

Effect of EDC* on antigenicity of killed S. typhosa

\begin{tabular}{|c|c|c|c|c|}
\hline \multirow{2}{*}{$\begin{array}{l}\text { Reagent } \\
\text { (human) }\end{array}$} & \multirow[b]{2}{*}{ Supplement } & \multirow{2}{*}{$\underset{\text { activity }}{\operatorname{EDC}}$} & \multicolumn{2}{|c|}{$\begin{array}{c}\text { Agglutinin titersł of rabbits } \\
\text { receiving } 10 \times 10^{6} \text { heat-killed } \\
\text { S.typhosa after interaction } \\
\text { with }\end{array}$} \\
\hline & & & $0.5 \mathrm{ml}$ & $0.1 \mathrm{ml}$ \\
\hline $\begin{array}{l}\text { ACD plasma } \\
\text { ACD plasma }\end{array}$ & $\begin{array}{l}\text { none } \\
\mathrm{Ca}^{++} 5.4 \times 10^{-2} \mathrm{M}\end{array}$ & \pm & $\begin{array}{r}9 \\
254\end{array}$ & $\begin{array}{r}35 \\
1,280\end{array}$ \\
\hline $\begin{array}{l}\text { ACD plasma, dialyzed } \\
\text { ACD plasma, dialyzed }\end{array}$ & $\begin{array}{l}\text { none } \\
\text { sodium citrate } \\
\qquad 2 \times 10^{-2} \mathrm{M}\end{array}$ & $\overline{+}$ & $\begin{array}{r}422 \\
20\end{array}$ & $\begin{array}{r}1,470 \\
184\end{array}$ \\
\hline $\begin{array}{l}\text { Serum } \\
\text { Serum }\end{array}$ & $\begin{array}{l}\mathrm{Ca}^{++} 2.7 \times 10^{-2} \mathrm{M} \\
\mathrm{EDTA} \\
\quad 0.5 \times 10^{-2} \mathrm{M}\end{array}$ & $\bar{t}$ & $\begin{array}{r}1,100 \\
6\end{array}$ & $\begin{array}{r}2,230 \\
368\end{array}$ \\
\hline Controls (saline) & & & \multicolumn{2}{|c|}{3,380} \\
\hline
\end{tabular}

* Endotoxin-detoxifying component.

† As determined in the tumor damage assay.

$\ddagger$ Mean titers for groups of 5 rabbits.

$1: 2,100$ for viable organisms. Larger numbers ranging from 5 to $50 \times 10^{7}$ organisms evoked relatively little further increase in titer. To provide a suitable antigenic stimulus a single intravenous immunizing dose of $10 \times 10^{6}$ organisms was chosen. This had the further advantage of being directly comparable to the bactericidal test in which the same number of organisms was used.

Elimination of the antigenicity of killed S. typhosa by EDC. It was shown in a preceding section that the endotoxin of killed typhoid bacilli is inactivated by a humoral agent with the distinctive attributes of EDC. EDC activity is readily suppressed by divalent cations such as $\mathrm{Ca}^{++}, \mathrm{Mg}^{++}$, $\mathrm{Mn}^{++}$and $\mathrm{Ba}^{++}$and requires certain anions to exert its effect on endotoxin (3). These characteristics were utilized to demonstrate that this component likewise affected the antigenicity of heat-killed typhoid bacilli. The antibody response of rabbits to such organisms, which had been incubated at $37^{\circ} \mathrm{C}$ for one hour with one or another source of EDC activity, was determined. The same results were obtained in the two experiments performed, each involving 65 rabbits. The data from one of these are given in Table IX. It is evident that elimination of antigenicity was effected by those reagents known to have EDC activity, i.e., citrated (ACD) plasma, such plasma as had been dialyzed and then supplemented with sodium citrate, and serum in which the divalent cation was bound with a chelating agents such as EDTA
(4). On the other hand, the bacilli which had been incubated in the very same plasma or serum in which EDC had been suppressed by the prior addition of calcium, or by dialysis against water, had undiminished antigenic potency.

Inactivation of antigenicity of viable bacilli by the complement system. Viable typhoid bacilli after interaction with fresh human serum in vitro no longer elicited high levels of typhoid agglutinins in rabbits. To determine the factors in serum responsible for this elimination of antigenicity, viable bacilli were interacted for one hour at $37^{\circ} \mathrm{C}$ with human serum which had been rendered deficient in one or another of the components of complement. Each reaction mixture was examined in parallel in bactericidal and antigenicity tests. One such experiment, summarized in Table $\mathrm{X}$, shows that fresh serum, which is highly effective in rendering the bacilli nonviable and nonantigenic, no longer exerts this effect when made deficient in divalent cation or any of the components of complement. The interrelationship of these biologic effects of serum was further substantiated in studying the rate of the reaction. Human serum and a suspension of viable bacilli were mixed in a water bath at $4^{\circ} \mathrm{C}$ and aliquots were transferred to a $37^{\circ} \mathrm{C}$ bath in which they remained for varying intervals ranging from 5 to 60 minutes. The reaction was terminated by returning the aliquots to the $4^{\circ} \mathrm{C}$ bath, after which the viable count and the antigenicity of the 
TABLE $X$

Requirements for the elimination by serum of viability and antigenicity of $S$. typhosa

\begin{tabular}{ccc}
\hline \hline $\begin{array}{c}\text { Human serum reagent } \\
\text { interacted with 10 } \times 10^{6} \\
S . \text { typhosa for } 1 \mathrm{hr} \\
\text { at } 37^{\circ} \mathrm{C} \\
(0.2 \mathrm{ml})\end{array}$ & $\begin{array}{c}\text { Bactericidal } \\
\text { effect } \\
\text { viable count } \\
\times 10^{6}\end{array}$ & $\begin{array}{c}\text { Antigenic } \\
\text { response elicited } \\
\text { in rabbits } \\
\text { mean agglutinin } \\
\text { titers* }\end{array}$ \\
\hline Untreated serum & 0.013 & 46 \\
$\mathrm{R} 1$ & 6.0 & 640 \\
$\mathrm{R} 2$ & 3.6 & 904 \\
$\mathrm{R} 3$ & 7.1 & 844 \\
$\mathrm{R} 4$ & 5.5 & 844 \\
EDTA-treated & 2.0 & 1,120 \\
$\Delta 56^{\circ}$ C, $\frac{1}{2}$ hr & 11.2 & 1,940 \\
Saline controls & 9.6 & 1,940 \\
\hline
\end{tabular}

* Five rabbits per group.

bacilli in each of the reaction mixtures were determined. Table XI illustrates the results of one such experiment; the aliquot of the reaction mixture maintained at $4^{\circ} \mathrm{C}$ served as the zero minute control. Incubation at $37^{\circ} \mathrm{C}$ of the bacilli and $56^{\circ} \mathrm{C}$-serum resulted in no change in viable count or antigenicity. The data showed that within five minutes, at $37^{\circ} \mathrm{C}$, there was a striking reduction in viable count which was paralleled by an analogous elimination of the antigenic capability of the bacilli.

\section{DISCUSSION}

The findings in this paper have led to the conclusion that the endotoxin of intact typhoid bacilli can be inactivated; two different humoral systems, viz., one which requires complement and one which does not, have been found to be operative for viable and killed bacilli, respectively. It has not been possible to make any sharp distinction between the endotoxin on killed and viable bacilli as judged by the various nonspecific effects they elicit in the host. This similarity in their reactivity extends also to the production of specific antibody in rabbits. There is no direct evidence that the loss of viability brought about by heating at $56^{\circ} \mathrm{C}$, or treatment with merthiolate. involves any major change in the endotoxic complex itself. For these reasons it might have been anticipated that there would be no difference in the manner in which endotoxins of viable and heat-killed bacilli are inactivated. However, as this report shows, such a difference clearly exists.

In seeking to explain the basis for this unexpected difference in reactivity, it was appreciated
TABLE XI

Rate of the serum reaction with bacilli as measured by loss of viability and antigenicity

\begin{tabular}{|c|c|c|}
\hline $\begin{array}{l}\text { Time allotted for } \\
\text { in vitro interaction } \\
\text { of } 0.5 \text { ml human } \\
\text { serum and } 10 \times 10^{6} \\
S . \text { typhosa } \\
\text { (min) }\end{array}$ & $\begin{array}{c}\text { Bactericidal } \\
\text { effect } \\
\text { viable count } \\
\times 10^{6}\end{array}$ & $\begin{array}{c}\text { Antigenic } \\
\text { response elicited } \\
\text { in rabbits } \\
\text { mean agglutinin } \\
\text { titers* }\end{array}$ \\
\hline 0 & 12.5 & 1,940 \\
\hline 5 & 0.0093 & 105 \\
\hline 10 & 0.0012 & 92 \\
\hline 20 & 0.0013 & 30 \\
\hline 60 & 0.0005 & 120 \\
\hline
\end{tabular}

${ }^{*}$ Five rabbits per group.

that some chemical alteration in the endotoxin might nonetheless occur as a result of the treatment by which the bacilli were rendered nonviable. Such a postulated change need not have been reflected in altered biologic activity but could be critically important for interaction of the viable bacilli with the complement system. Furthermore, certain functions inherent in the viable cell wall may preclude interaction of EDC with endotoxin on the bacterial surface. For instance, the functioning of the viable cell wall might render the ionic environment unfavorable for the unique ionic requirements of EDC activity.

In our earlier work on EDC (1-4), and in the present experiments as well, we have of necessity employed whole serum or plasma to effect various changes in isolated endotoxin and in typhoid bacilli. It is obvious that serum contains many biologically active systems and is an extremely complex medium. The agents in serum responsible for the effects being studied are recognized and identified primarily by indirect evidence and not on the basis of chemical definition. Thus distinctive features of EDC activity include: $a$ ) its suppression by divalent cation; $b$ ) its anionic requirement; $c$ ) no demonstrable participation of antibody; $d$ ) its resistance to destruction upon dialysis against water ; $e$ ) its relative heat stability.

On the other hand, the complement system plainly differs in each of these respects. Furthermore, the standard procedures for identifying each of the components of complement by virtue of its inactivation has been shown to leave EDC activity unaltered. It is therefore evident that adequate criteria exist for distinguishing between these two systems. On the basis of these criteria, 
means are readily available for suppressing one system while facilitating operation of the other.

The information obtained in this study has shown that the array of factors in normal serum which are required for bactericidal effect (antibody, complement and divalent cation) are the very same components which are needed to eliminate such endotoxic attributes of viable bacilli as the induction of tumor damage and the production of antibody. Such information as was obtained indicates that these changes are simultaneous events. In any case it has not been possible to separate killing of the bacilli by serum from the loss of their toxic and antigenic properties. These facts in themselves do not prove that the changes brought about in the endotoxin of the bacteria by the complement system are necessarily critical for the bactericidal effect. Indeed, it is conceivable that the changes in endotoxin that have been measured are even incidental to the killing process. However, these findings do imply that, at some stage of the interaction between serum and organisms, endotoxin is the substrate for one of the many enzymatic reactions which undoubtedly come into play. This concomitant elimination of endotoxic attributes of typhoid bacilli in the serum bactericidal process has obvious important implications for the host-parasite relationship.

It has been proposed that the somatic antigen on the bacterial surface is the key substrate for serum bactericidal activity (11). However, no direct evidence has heretofore been obtained to substantiate this proposal. The present work, which shows that inactivation of endotoxin is intimately associated with the killing of $S$. typhosa by the normal serum bactericidal mechanism, constitutes evidence that indirectly supports this view. These alterations in the endotoxin of the viable bacillus, which can readily be measured, may offer special advantages for further delineation of the complex sequence of events in the killing of bacteria by serum.

It has been reported recently that fresh serum can produce morphological alterations in the cell wall of Salmonella (12) and Shigella species (13) which results in their conversion to spheroplasts. It has not been established that the formation of these spheroplasts is an essential step in the process by which serum kills these bacilli. The es- sential factors and conditions of the serum bactericidal mechanism appear to be less complex than are the requirements for the serum conversion of typhoid bacilli to spheroplasts. Although the inactivation of endotoxic activity undoubtedly occurs under these more complex circumstances, it also can be effected under conditions which do not favor spheroplast formation. Therefore, there is, at present, no evidence that would directly relate the inactivation of the bacterial endotoxin to the changes in the cell wall which result in spheroplast formation.

We have previously discussed the advantages and limitations of the various host responses to endotoxin with regard to their use for the assay of endotoxin and thereby for the measurement of alterations produced in endotoxin by biologic agents (2). It was pointed out that of the considerable array of reactions in the mammalian host which are known to be elicited by endotoxin very few provide discriminating quantitation and acceptable consistency. The two host responses to endotoxin which have been utilized in the present work had been found to meet these requirements in related studies. Furthermore, the changes detected with these two systems were shown to be equally applicable to still other reactions of the host. Accordingly, the changes in the endotoxin of intact $S$. typhosa which have been measured by loss of antigenicity, and the capacity to induce tumor damage, are considered to be indicative of major alterations in this complex. Even though the end products of the interactions are equally ineffective in eliciting host responses, it does not necessarily follow that EDC alters the endotoxic complex in the same way as does the complement-antibody system. The nature of the changes in the endotoxic complex brought about by either of these systems is presently unknown.

In the course of these studies other information has been obtained which has little direct bearing on the primary issues under consideration. Inasmuch as these incidental findings contribute to areas which have attracted interest they are summarized briefly:

a) In the past it was not possible to determine precisely the time, after injection of polysaccharide, when the pattern of events leading to tumor damage by the injected endotoxin became 
irreversible (14). In the present work, the use of viable typhoid organisms as a source of endotoxin was advantageous in that it was possible to inactivate or detoxify the bacilli by the separate administration of serum. The sequence of events leading to the production of hemorrhagic necrosis could be interrupted by the injection of serum within an interval of one hour after the bacilli. After this time interval the administration of serum no longer influenced the ultimate outcome despite the absence of any change detected in the tumor at the time the serum was given.

b) Past evidence has led to the assumption that mouse serum is deficient in both the second and third components of complement (15), to which has been attributed the lack of bactericidal and hemolytic activity of such serum in vitro. The present report presents further evidence in support of this contention, in that the addition to mouse serum of either R2 or R3, prepared from human serum by standard methods, failed to provide a combination with bactericidal activity. However, human serum from which $\mathrm{C}^{\prime} 2$ had been eliminated by heating (one-half hour at $52^{\circ} \mathrm{C}$ ) exhibited highly effective bactericidal activity when combined with mouse serum. Thus, different results were obtained on supplementing mouse serum depending on the method of preparation of R2. However, when such heated human serum was combined with mouse serum which had also been heated at $52^{\circ} \mathrm{C}$, bactericidal activity was not restored. It is therefore clear that heated human serum is capable of supplementing mouse serum with some substance not present in R2 prepared by dialysis. Although mouse serum has been considered as lacking in $\mathrm{C}^{\prime} 2$, the present findings show that it contains a component which, in its biologic effect and in its heat lability, behaves like $C^{\prime} 2$.

\section{SUMMARY}

Alteration of the endotoxin of Salmonella $t y$ phosa in its native state on the bacterial surface, after incubation with serum, was studied. Changes in endotoxic behavior were measured by the loss of two characteristic attributes; viz., induction of hemorrhagic necrosis in mouse Sarcoma 37, and stimulation of specific antibody formation in rab- bits. The endotoxic activity of typhoid bacilli killed by heat or by chemical treatment was inactivated by endotoxin-detoxifying component (EDC), the same agent previously shown to affect isolated endotoxin, but was not inactivated by antibody and complement. In contrast, the endotoxic activity of viable bacilli was not affected by EDC but was eliminated by antibody and complement, the recognized bactericidal system of normal serum. Viability was thus the critical factor in determining which of these two humoral systems exerted an effect on the endotoxin of typhoid bacilli.

\section{REFERENCES}

1. Landy, M., Skarnes, R. C., Rosen, F. S., Trapani, R-J., and Shear, M. J. Inactivation of biologically active ("Endotoxic") polysaccharides by fresh human serum. Proc. Soc. exp. Biol. (N. Y.) 1957, 96, 744.

2. Skarnes, R. C., Rosen, F. S., Shear, M. J., and Landy, $M$. Inactivation of endotoxin by a humoral component. II. Interaction of endotoxin with serum and plasma. J. exp. Med. 1958, 108, 685.

3. Rosen, F. S., Skarnes, R. C., Landy, M., and Shear, M. J. Inactivation of endotoxin by a humoral component. III. Role of divalent cation and a dialyzable component. J. exp. Med. 1958, 108, 701.

4. Landy, M., Trapani, R-J., and Shear, M. J. Inactivation of endotoxin by a humoral component. IV. Alteration in the immunological properties of typhoid endotoxin. J. exp. Med. 1959, 110, 731.

5. Bennett, I. L., Jr., and Cluff, L. E. Bacterial pyrogens. Pharmacol. Rev. 1957, 9, 427.

6. Ecker, E. E., Pillemer, L., and Seifter, S. Immunochemical studies on human serum. I. Human complement and its components. J. Immunol. 1943, 47, 181.

7. Pillemer, L., Blum, L., Lepow, I. H., Wurz, L., and Todd, E. W. The properdin system and immunity. III. The zymosan assay of properdin. J. exp. Med. 1956, 103, 1.

8. Shear, M. J., Perrault, A., and Adams, J. R., Jr. Chemical treatment of tumors. IV. Method employed in determining the potency of hemorrhageproducing bacterial preparations. J. nat. Cancer Inst. 1943, 4, 99.

9. Marcus, S., Esplin, D. W., and Donaldson, D. M. Lack of bactericidal effect of mouse serum on a number of common microorganisms. Science 1954, 119, 877.

10. Shilo, M., and Wolman, B. Activities of bacterial levans and of lipopolysaccharides in the processes of inflammation and infection. Brit. J. exp. Path. 1958, 39, 652 . 
11. Rowley, D., Ali, W., and Jenkin, C. R. A reaction between fresh serum and lipopolysaccharides of gram-negative bacteria. Brit. J. exp. Path. 1958, 39, 90.

12. Muschel, L. H., Carey, W. F., and Baron, L. S. Formation of bacterial protoplasts by serum components. J. Immunol. 1959, 82, 38.

13. Michael, J. G., and Braun, W. Serum spheroplasts of Shigella dysenteriae. Proc. Soc. exp. Biol. (N. Y.) 1959, 100, 422.

14. Diller, I. C. Nuclear changes produced by $S$. marcescens (B. prodigiosus) polysaccharide in Approaches to Tumor Chemotherapy. Washington, D. C., Amer. Ass. Advanc. Sci., 1947, p. 260.

15. Muschel, L. H., and Muto, T. Bactericidal reaction of mouse serum. Science 1956, 123, 62. 